\title{
New estimates of orangutan density in Sungai Palin watershed, Kapuas Hulu, West Kalimantan, Indonesia
}

\author{
Achmad Yanuar, Jan Fehse, David Chivers and Jito Sugardito
}

\begin{abstract}
Pongo pygmaeus pygmaeus is a subspecies of Bornean orangutan whose distribution is restricted to the northern part of the Kapuas River, West Kalimantan, and is categorized as Critically Endangered. In October 2017 we carried out a survey to estimate orangutan density in the peat-swamp forests of the Sungai Palin watershed, of the upper Kapuas river, Kapuas Hulu, West Kalimantan, Indonesia. Surveys for orangutans in 1991, in nearby Nanga Awen, had indicated the presence of orangutans in the peat-swamp forests of this area. We used distance sampling techniques to estimate orangutan densities from nest observations. We recorded 76 orangutan nests along $4.5 \mathrm{~km}$ transects in Sungai Palin in 2017, and 71 orangutan nests were observed along $4.3 \mathrm{~km}$ transects in Nanga Awen in 1991, giving densities of 1.29 and 2.62 individuals $/ \mathrm{km}^{2}$, respectively. The results of this orangutan survey can be used as a baseline for monitoring of orangutan populations for conservation and management of this watershed landscape.
\end{abstract}

Keywords Indonesia, limited production forest, Nanga Awen, orangutan, Pongo pygmaeus pygmaeus, small population, Sungai Palin, transect survey

Three Asian great ape species occur in Sumatra and 1 Borneo: Pongo abelii and Pongo tapanuliensis (Nater et al., 2017) in northern Sumatra and Pongo pygmaeus in Borneo. The latter has three subspecies: the north-western Bornean orangutan Pongo pygmaeus pygmaeus, the central Bornean orangutan Pongo pygmaeus wurmbii and the north-eastern Bornean orangutan Pongo pygmaeus morio (Groves, 1999, 2001), all of which are categorized as Critically Endangered on the IUCN Red List (Ancrenaz et al., 2016). Pongo pygmaeus pygmaeus is restricted to the upper Kapuas River in West Kalimantan (Indonesia) and Sarawak (Malaysia). It has the smallest population of the three subspecies, with a total of 3,000-4,500 individuals (Wich et al., 2008) of which there are c. 1,300 in Sarawak

ACHMAD YANUAR (Corresponding author, (D) orcid.org/0000-0001-8015-7793) and Jito Sugardjito Department of Biology, Universitas Nasional, Jl. RM. Harsono, Jakarta 12550, Indonesia. E-mail ay232ster@gmail.com

JAN FeHSE Value for Nature Ltd., Oxford, UK, and LTS International Ltd. Edinburgh, UK

David Chivers Selwyn College, University of Cambridge, Cambridge, UK

Received 10 January 2019. Revision requested 12 February 2019.

Accepted 15 July 2019. First published online 25 November 2019.
(Ancrenaz et al., 2005; Ancrenaz, 2006; WWF Malaysia, 2018). Bornean orangutans are known to live in primary and secondary forests and are typically found in peatswamp forest and lowland dipterocarp forest at $<500 \mathrm{~m}$ altitude (Rijksen \& Meijaard, 1999). Only an estimated $25 \%$ of orangutan populations live within protected areas (Singleton et al., 2004; IUCN, 2012).

Most orangutan range remains poorly documented, and updating and expanding baseline data, especially in unprotected areas such as limited production forests (forests in which there is selective logging) and production forests, is essential (Wich et al., 2012). The rate of deforestation in Kalimantan is increasing, threatening orangutan habitats. Improved management is thus needed for conserving orangutan populations outside protected areas by involving all stakeholders, developing and implementing best management practices, and working with local communities to avoid or mitigate negative human-wildlife interactions.

Two protected areas, Danau Sentarum Wildlife Reserve and Betung Kerihun National Park, in the upper Kapuas watershed, were home to relatively large populations of the Bornean orangutan until the 1990s (Meijaard et al., 1996). However, during 1973-1997 almost 30\% of habitat disappeared in and around Danau Sentarum Wildlife Reserve (Russon et al., 2000) and it is likely that the orangutan population in this area has declined. Orangutans are, however, still commonly encountered in the unprotected areas of Sungai Palin and Nanga Awen, which lie between Danau Sentarum Wildlife Reserve and Betung Kerihun National Park (Fig. 1), although anecdotal evidence suggests that the number of orangutans in these two areas has fallen as a result of forest degradation.

In October 2017 we conducted orangutan population surveys in peat-swamp forests that are limited production forests under the authority of the local forest department of Kapuas Hulu and the local community of Nanga Lauk village. We established five line transects (0.6-1.2 km long, with a total length of c. $4.5 \mathrm{~km}$ ) from the bank of the Palin River in Sungai Palin towards peat-swamp forests (Fig. 1). We counted orangutan nests along these transects in 5 days of survey walks, each with two observers.

A previous survey, using the the same method, undertaken in 1991 in Nanga Awen, c. 20 km away from Sungai Palin in the same landscape, recorded orangutan nests along three transects (1.0-1.2 km long, with a total length of $4.3 \mathrm{~km}$ ). Here we also analyse these previously unpublished data, to determine orangutan density in August 1991 as a reference point for comparison with our 2017 survey. 


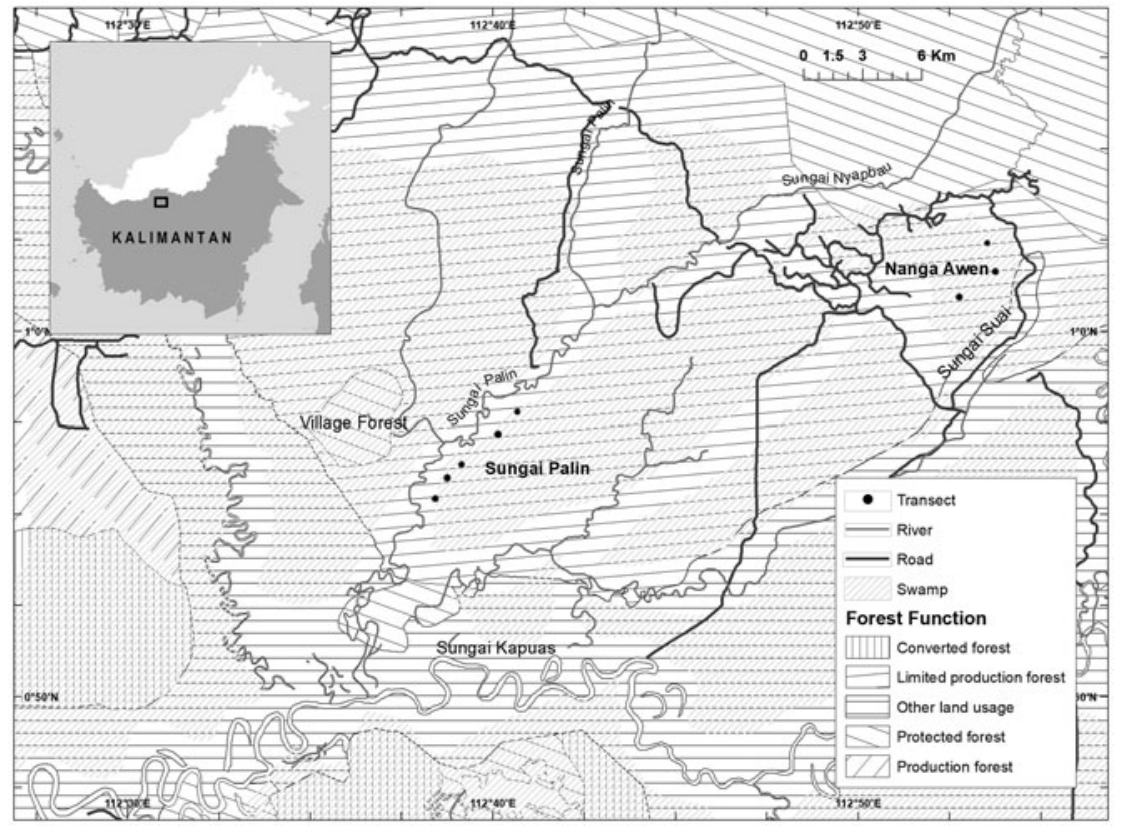

FIG. 1 Sungai Palin and Nanga Awen, indicating the location of the transects used to survey for orangutan nests in limited production forest and peat swamp forests, in Kapuas Hulu, west Kalimantan, Indonesia.
In both 2017 and 1991 the perpendicular distance of all nests visible from each transect was measured with a tape. Density estimates for both sets of data were computed using the signed nest-count technique (Schaik et al., 1995). We used Distance 6.o (Thomas et al., 2010) to estimate the effective strip width and thus determine the survey area and estimate nest density in both Sungai Palin and Nanga Awen. Distance uses a detection curve to estimate detectability (Buckland et al., 1993) as a function of the perpendicular distance of nests from the centre of the transect (Cattau et al., 2014). We calculated nest density as $D n=n / L 2 w$, where $D n$ is nest density, $n$ is the number of nests counted on a transect; $L$ is transect length (in $\mathrm{km}$ ), and $w$ is the effective transect strip width (measured in $\mathrm{m}$, converted to $\mathrm{km}$ ), and orangutan density was calculated as $D o=D n / p r t$, where $D o$ is orangutan density, $p$ is the proportion of nest builders, $r$ is daily nest production rate per orangutan and $t$ is nest decay rate (Russon et al., 2001; Morrogh-Bernard et al., 2003; Johnson et al., 2005; Van Schaik et al., 2005). We used values of $p=0.85, r=1.0$ and $t=202$, determined in studies (Ancrenaz et al., 2004) at sites with a similar habitat type and disturbance level to our survey area (peat-swamp forest of Lower Kinabatangan and surrounding areas in Malaysia; Ancrenaz et al., 2005).

We observed a total of 76 orangutan nests along a total of $4.5 \mathrm{~km}$ of transects in Sungai Palin, and 71 nests along a total of $3.4 \mathrm{~km}$ of transects were observed in Nanga Awen. Mean nest densities were $222 \pm$ SE 82.14 and $499 \pm$ SE 162.43 per $\mathrm{km}^{2}$ in Sungai Palin and Nanga Awen, respectively (Table 1). The density estimate for Sungai Palin in 2017 is slightly lower than that for Nanga Awen in 1991 (Table 1), suggesting that orangutan density may have halved between these dates and that the orangutan population outside protected areas remains relatively low. The building of new roads is one of the threats to the orangutan subpopulation on Sungai Palin (Local people, pers. comm., 2017).

Estimated orangutan density in Sungai Palin is lower than in the peat-swamp forest of Danau Sentarum National Park and the peat-swamp forest of the former Mega-Rice project in central Kalimantan, higher than that in the lowland and hill lowland forests of Betung Kerihun National Park, but similar to that in Sebangau National Park (Table 2). Many factors influence orangutan density in disturbed forests, including food availability, connectivity between forest remnants, and whether orangutans can survive after habitat loss. The logging concession in the area of Nanga Lauk village has been inactive since at least 2003 (Local people, pers. comm., 2017), and there are no reports of local people hunting orangutans in the Nanga Lauk forest area, even though orangutans sometimes take honey from local beehives (Local people, pers. comm., 2017).

Protection forests surrounding the Sungai Palin and Nanga Awen landscape are under the jurisdiction of the district forestry agency, but are managed by the local community as the Nanga Lauk Village Forest (Hutan Desa). The community is allowed to extract non-timber forest products only. This initiative to include the local community in managing forest land has helped to protect the orangutan, as evidenced by the fact that logging ceased in 2003. The people of Nanga Lauk plan to expand the area of this Village Forest (Damayanti et al., 2016).

More detailed surveys of the orangutan and its habitat are required in this area, so that the orangutan population can be appropriately managed. As Sungai Palin and Nangan Awen lie between Danau Sentarum Wildlife Reserve and Betung Kerihun National Park, awareness amongst the 
TABLE 1 Effective strip width ( \pm SE), Akaike's information criterion (AIC), \% coefficient of variation (CV), mean density of orangutan nests ( \pm SE, with $95 \% \mathrm{CI}$ ) and estimate of mean individual density (with 95\% CI) in peat swamp forests of Sungai Palin surveyed in 2017, and Nanga Awen surveyed in 1991.

\begin{tabular}{lllllll}
\hline & & & & \multicolumn{2}{l}{ Mean density $\left(\right.$ per km $\left.{ }^{2}\right)$} \\
\cline { 5 - 7 } Location & Effective strip width \pm SE $(\mathrm{km})$ & AIC & \% CV & Nests \pm SE $(95 \%$ CI $)$ & Individuals $(95 \%$ CI) \\
\hline Sungai Palin & $0.011 \pm 0.0014$ & 470.34 & 37.01 & $222 \pm 82.14(88.32-557.84)$ & $1.29(0.51-3.25)$ \\
Nanga Awen & $0.013 \pm 0.0027$ & 446.26 & 36.12 & $449 \pm 162.43(175.11-1,154.60)$ & $2.62(1.02-6.72)$ \\
\hline
\end{tabular}

TABLE 2 Summary of information available on the density of the three Bornean orangutan subspecies, based on nest count surveys.

\begin{tabular}{llccl}
\hline Location & Subspecies & Survey year & Density $\left(\right.$ per $\left.\mathrm{km}^{2}\right)$ & Source \\
\hline Sangkulirang peninsula & P. pygmaeus morio & 2003 & $0.82-5.25$ & Marshall et al. (2007) \\
Nanga Awen & P. pygmaeus pygmaeus & 1991 & 2.62 & This study \\
Danau Sentarum National Park & P. pygmaeus pygmaeus & 1996 & $3.29-4.09$ & Russon et al. (2001) \\
Betung Kerihun National Park & P. pygmaeus pygmaeus & 2005 & $0.20-1.01$ & Ancrenaz (2006) \\
Sungai Palin & P. pygmaeus pygmaeus & 2017 & 1.29 & This study \\
Sebangau National Park & P. pygmaeus wurmbii & $1995-1996$ & $0.44-1.72$ & Morrogh-Bernard et al. (2003) \\
Mega-Rice project & P. pygmaeus wurmbii & 2009 & $1.62-4.63$ & Cattau et al. (2014) \\
\hline
\end{tabular}

local communities of the importance of the orangutan population outside these protected areas is essential to help maintain connectivity between the orangutan populations.

Our surveys and calculations of orangutan density form a baseline for monitoring this orangutan population and for informing conservation action and management of non-timber forest products in the watershed landscapes of Sungai Palin. The orangutan population in the landscape of Sungai Palin, Nanga Awen and surrounding areas shold be a priority for community-based conservation.

Acknowledgements We thank LTS International for giving AY the opportunity to survey orangutans in Sungai Palin peat land forest while he conducted a biodiversity survey in Nanga Lauk Village Forest for the ADB-funded project Sustainable Forest and Biodiversity Management in Borneo, Fauna \& Flora International, UK, for the data from the 1991 surveys in Nanga Awen, the Nanga Lauk community, especially Simon, Hamdi and Yosep who helped us in Sungai Palin, and Chaerul Saleh and I Made Wedana, the orangutan survey team in Nanga Awen.

Author contributions Study design and field work: AY; data analysis: AY; writing: all authors.

\section{Conflicts of interest None.}

Ethical standards This research did not involve human subjects, experimentation with animals or collection of specimens, and abided by the Oryx guidelines on ethical standards.

\section{References}

Ancrenaz, M. (2006) Consultancy of Survey Design and Data Analysis at Betung Kerihun National Park, Indonesia. WWF Indonesia, Jakarta, Indonesia.

Ancrenaz, M., Calaque, R. \& Lackman-Ancrenaz, I. (2004) Orangutan (Pongo pygmaeus) nesting behavior in disturbed forest
(Sabah, Malaysia): implication for nest census. International Journal of Primatology, 25, 983-1000.

Ancrenaz, M., Gimenez, O., Ambu, L., Ancrenaz, K., Andau, P., Goossens, B. et al. (2005) Aerial survey give new estimates for orangutans in Sabah, Malaysia. PLOS Biology, 3, e3.

Ancrenaz, M., Gumal, M., Marshall, A.J., Meijaard, E., Wich, S.A. \& Husson, S. (2016) Pongo pygmaeus (errata version published in 2018). In The IUCN Red List of Threatened Species 2016:

e.T17975A123809220. Http://dx.doi.org/10.2305/IUCN.UK.2016-1. RLTS.T17975A17966347.en [accessed 8 August 2019].

Buckland, S.T., Anderson, D.R., Burnham, K.P. \& LaAke, J.L. (1993) Distance Sampling: Estimating Abundance of Biological Populations. Chapman and Hall, London, UK.

Cattau, M.E., Husson, S. \& Cheyne, S.M. (2014) Population status of the Bornean orangutan Pongo pygmaeus in a vanishing forest in Indonesia: the former Mega Rice Project. Oryx, 49, 473-48o.

Damayanti, E.L., Hanjoyo \& Berry, N.L. (2016) Sustainable Forest and Biodiversity Management Borneo. Biodiversity Ecosystem Service. Unpublished report. LTS-International and Diameter, Bogor, Indonesia.

Groves, C.P. (1999) The taxonomy of orangutans. In Orangutan Action Plan (ed. C. Yeager), pp. 27-30. Direktorat Jenderal Perlindungan dan Konservasi Alam, Jakarta, World Wildlife Fund, Indonesia, and Center for Environmental Research and Conservation, Columbia University, New York, USA.

Groves, C.P. (2001) Primate Taxonomy. Smithsonian Institution Press, Washington, DC, USA.

IUCN (2012) IUCN Red List Categories and Criteria: Version 3.1. 2nd edition. IUCN, Gland, Switzerland and Cambridge, UK. Http:// www.iucnredlist.org/technical-documents/categories-and-criteria [accessed November 2019].

Johnson, A.E., Knott, C.D., Pamungkas, B., Pasaribu, M. \& Marshall, A.J. (2005) A survey of the orang-utan (Pongo pygmaeus wurmbii) population in and around Gunung Palung National Park, west Kalimantan, Indonesia based on nest count. Biological Conservation, 121, 495-507.

Marshall, A.J., Salas, L.A., Stephan, S., Nardiyono, Engström, L., Meijaard, E. \& S TAnley, A. (2007) Using of limestone karst forests by Bornean orang-utans (Pongo pygmaeus morio) in the Sangkulirang peninsula, east Kalimantan, Indonesia. American Journal of Primatology, 69, 212-219. 
Meija ard, E., Dennis, R.A. \& Erman, A. (1996) Orangutan Conservation in and Around the Danau Sentarum Wildlife Reserve, West Kalimantan; Management Implications. Unpublished report. Department of Forestry (PHPA) and TROPENBOS-ODA, Bogor, Indonesia.

Morrogh-Bernard, H., Husson, S., Page, S.E. \& Rieley, J.O. (2003) Population status of the Bornean orangutan (Pongo pygmaeus) in the Sebangau peat swamp forest, Central Kalimantan, Indonesia. Biological Conservation, 110, 114-152.

Nater, A., Mattle-Greminger, M.P., Nurcahyo, A., Nowak, M.G., De Manuel, M., Desai, T. et al. (2017) Morphometric, behavioral, and genomic evidence for a new orangutan species. Current Biology, 27, 1-27.

Rijksen, H.D. \& Meija ard, E. (1999) Our Vanishing Relative: the Status of Wild Orangutans at the Close of the Twentieth Century. Kluwer Academic Publisher, Dordrecht, The Netherlands.

Russon, A.E., Erman, A. \& Dennis, R. (2001) The population and distribution of orangutans (Pongo pygmaeus pygmaeus) in and around the Danau Sentarum Wildlife Reserve, West Kalimantan, Indonesia. Biological Conservation, 97, 21-28.

Russon, A.E., MeijaArd, E. \& Dennis, R.A. (2000) Declining orangutan population in and around Danau Sentarum National Park, West Kalimantan. Borneo Research Bulletin, 31, 372-384.

Singleton, I., Wich, S.A., Husson, S., Stephen, S., UtAmiAтмоко, S.S., Leighton, M. et al. (2004) Orangutan Population and Habitat Viability Assessment: Final Report. IUCN/Species
Survival Commission Conservation Breeding Specialist Group, Apple Valley, USA.

Thomas, L., Buckland, S.T. \& Rexstard, E.A. (2010) Distance software: design and analysis of distance sampling survey for estimating population size. Journal of Applied Ecology, $47,5-14$.

Van Schaik, C.P., Azwar. \& Priatna, D. (1995) Population estimates and habitat preferences of orang-utans based on line transects of nests. In The Neglected Ape (eds R.D. Nadler, B.F.M. Galdikas, L.K. Sheeran \& N. Rosen), pp. 109-116. Plenum Press, New York, USA.

VAn Schaik, C.P., Wich, S.A., Utami, S.S. \& Odom, K. (2005) A simple alternative to line transects of nests for estimating orangutan densities. Primates, 46, 249-254.

Wich, S.A., Gaveau, D., Abram, N., Ancrenaz, M., Baccini, A., BREND, S. et al. (2012) Understanding the impacts of land-use policies on a threatened species: is there a future for the Bornean orangutan? PLOS ONE, 7, e49142.

Wich, S.A., Meijaard, E., Marshall, A.J., Husson, S., Ancrenaz, M., LACY, R.C. et al. (2008) Distribution and conservation status of the orang-utan (Pongo spp.) on Borneo and Sumatra: how many remain? Oryx, 42, 329-339.

WWF Malaysia (2018) Our Orangutans Are Fast Disappearing. Http://www.wwf.org.my/media_and_information/front_line_ stories/?25325/Our-Orangutans-Are-Fast-Disappearing [accessed 7 August 2019]. 